\title{
Acute Myelogenous Leukemia Associated with MLL-SEPT6 Rearrangement and TRAF3, FGFR3 Mutation: A Pediatric Case Report and Review of the Literature
}

\author{
Yao Chen ${ }^{1}$, Yiming Pan ${ }^{2}$, Li Zhang ${ }^{3}$, Xiaojuan Chen ${ }^{3}$, Wenyu Yang ${ }^{3}$, Ye Guo ${ }^{3}$, Xiaofan Zhu ${ }^{3}$ and Lixian Chang ${ }^{3, *}$ \\ 1 Department of hematology, Guangdong Province Traditional Chinese Medical Hospital, Guangzhou city, \\ Guangdong province, 510000, China; chenyaogzutcm@126.com \\ 2 First School of Clinical Medicine, Beijing University of Chinese Medicine, Beijing, 100029, China; \\ 396925641@qq.com \\ 3 Department of Pediatric Hematology, Institute of Hematology and Blood Diseases Hospital, Chinese A \\ cademy of Medical Sciences and Peking Union Medical College, Tianjin city, 300020, China. zhangli1@ \\ ihcams.ac.cn (L.Z.); chenxiaojuan@ihcams.ac.cn (X.C.); yangwenyu@ihcams.ac.cn (W.Y.); guoye@ihcams.a \\ c.cn (Y.G.); xfzhu@ihcams.ac.cn (X.Z.) \\ * Correspondence: clx.886@163.com
}

\begin{abstract}
The MLL gene is a site of frequent rearrangement in acute leukemia with multiple fusion partners, but MLL-SEPT6 rearrangement is rare in clinical leukemia practice, and only 13 cases have been reported. We describe the case of an acute myelogenous leukemia child with MLL-SEPT6 rearrangement whose age of onset and accompanying gene mutations differs from previous reports. Considering the poor prognosis of leukemia children with MLL-SEPT6 rearrangement and the unsatisfactory results of existing treatments, the study of this case may provide new theories for diagnosis and treatment of MLL-SEPT6-associated childhood acute leukemia.
\end{abstract}

Keywords: MLL-SEPT6; TRAF3; FGFR3; Acute Myelogenous Leukemia; Child.

\section{How to Use This Template}

\section{Introduction}

The mixed-lineage leukemia (MLL) gene is located on human chromosome 11q23, also known as KMT2A, ALL-1 or HRX [1-2]. The MLL gene-related rearrangements account for about $3 / 5$ of the acute myeloid leukemia-associated fusion genes and the prognosis varies with partner genes [3]. The fusion partners of the MLL gene can be divided into four categories: nuclear protein genes, cytoplasmic protein genes, histone acetyltransferase genes, and the septin family. The septin family is a highly conserved family of GTP-binding proteins that are associated with cell membrane, actin, and microtubule apoptosis [4]. Among them, five different septin family genes namely SEPT2, SEPT5, SEPT6, SEPT9, and SEPT11 were confirmed as fusion partners of MLL genes [5-10]. However, only thirteen cases of MLL-SEPT6 fusion gene mutation have been reported. Here, we describe the fourteenth case of MLL-SEPT6 with TRAF3, FGFR3 mutation in a child with acute myeloid leukemia (AML) and review the selected articles to further explore clinical features and treatment options of AML children with MLL-SETP6.

\section{Results}

The patient, a 10-year-old Chinese boy, inhales $4.5 \mathrm{ug}$ budesonide once a day after the diagnosis of asthma at 8-year-old. Except for asthma, he had no other medical past 
history. In April 2018, he was hospitalized due to intermittent fever and bone pain. Laboratory tests showed that white blood cell count: $3.7 \times 109 / \mathrm{L}$, neutrophil count: $2.0 \times 109 / \mathrm{L}$, hemoglobin level: 114g/L, blood platelet count: $245 \times 109$ / L; procalcitonin (PCT): 2.29 $\mathrm{ng} / \mathrm{ml}$, C-reaction protein (CRP) $>200 \mathrm{mg} / \mathrm{L}$, lactate dehydrogenase (LDH): $2167 \mathrm{IU} / \mathrm{L}$. His PCT and CRP decreased after anti-infective treatment but his clinical symptoms were not relieved and hemoglobin continued to decline, therefore he was transferred to another hospital for a higher level of care. In that hospital, he received anti-infective treatment with ceftriaxone, and then his fever and bone pain were relieved. The white blood cell and platelet counts were normal while four units of red blood cell were given as hemoglobin significantly decreased. From 2018.4.11 to 2018.5.8, four bone marrow examinations were performed and the results were summarized as follows:

Table 1. This is a table. Tables should be placed in the main text near to the first time they are cited.

\begin{tabular}{|c|c|c|c|c|c|c|}
\hline Date & Site & Cellularity & $\begin{array}{l}\text { Blast cells in } \\
\text { bone marrow }\end{array}$ & Fusion gene & Karyotype & $\begin{array}{c}\text { Blast cells } \\
\text { in peripheral } \\
\text { blood }\end{array}$ \\
\hline 4.11 & $\begin{array}{l}\text { Posterior supe- } \\
\text { rior iliac spine }\end{array}$ & \multicolumn{4}{|c|}{$\begin{array}{c}\text { Bone marrow presented a pale-yellow watery change with many necrosis } \\
\text { cells and cellular debris. }\end{array}$} & $8 \%$ \\
\hline 4.16 & $\begin{array}{l}\text { Posterior supe- } \\
\text { rior iliac spine } \\
\quad \text { (dry tap) }\end{array}$ & $\begin{array}{l}\text { Severe hypocellular- } \\
\text { ity }\end{array}$ & $25 \%$ & $\begin{array}{l}\text { MLL-SEPT6 } \\
\text { positive }\end{array}$ & - & $1 \%$ \\
\hline 4.25 & $\begin{array}{l}\text { Posterior supe- } \\
\text { rior iliac spine }\end{array}$ & Normocellularity & $6.8 \%$ & $\begin{array}{l}\text { MLL-SEPT6 } \\
\text { positive }\end{array}$ & $\begin{array}{l}\text { Normal } \\
\text { karyotype }\end{array}$ & $2 \%$ \\
\hline 5.8 & $\begin{array}{l}\text { Posterior supe- } \\
\text { rior iliac spine }\end{array}$ & Hypocellularity & $8.8 \%$ & $\begin{array}{l}\text { MLL-SEPT6 } \\
\text { positive }\end{array}$ & - & $2 \%$ \\
\hline 5.8 & Sternum & $\begin{array}{l}\text { Significant hypercel- } \\
\text { lularity }\end{array}$ & $5.2 \%$ & $\begin{array}{l}\text { MLL-SEPT6 } \\
\text { positive }\end{array}$ & - & $2 \%$ \\
\hline & & $\begin{array}{l}\text { On May 17, } 201 \\
\text { fever and bone pain } \\
\text { neutrophil count: } 3 \text {. } \\
\text { 109 / L, PCT: } 112 \mathrm{~m} \\
\text { Bone marrow smea } \\
\text { Simultaneously, bor } \\
\text { numbers of immatu } \\
\text { I (MF-1). Immuno } \\
\text { and myeloid cells w } \\
\text { other cell phenotype } \\
\text { Testing with a } \\
\text { identified a MLL- } \\
\text { MLL-SEPT6. Other } \\
\text { (NM-003300, Exon } \\
\text { c.490C>G, p.L164V) } \\
\text { (threshold value <2 } \\
\text { karyotype analysis. } \\
\text { the body and lower } \\
\text { in the enlarged sple } \\
\text { was initially diagn } \\
\text { FGFR3 mutations, } \\
\text { was below 20\% whi } \\
\text { refused to let him } \\
\text { cefoperazone sulbac } \\
\text { relieved. }\end{array}$ & $\begin{array}{l}\text { he was admitted } \\
\text { Laboratory tests s } \\
\times 109 \text { / L, hemo } \\
\text { / L, LDH: 411.9I } \\
\text { manifested a norr } \\
\text { marrow biopsy c } \\
\text { cells including } 1 \\
\text { henotyping analy } \\
\text { re basically matu } \\
\text { genetic sequencin } \\
\text { PT6 rearrangem } \\
\text { se, the next-gene } \\
1, \text { c.1688C }>\text { T, p.S5 } \\
\text { with frequency b } \\
7 \% \text { ) by FISH tes } \\
\text { PET scan illustra } \\
\text { mbs, consistent w } \\
n \text { suggesting secc } \\
\text { ed with acute m } \\
\text { LL-SEPT6 positiv } \\
\text { was not adequat } \\
\text { ceive chemother } \\
\text { im. Subsequently, }\end{array}$ & $\begin{array}{l}\text { our departmer } \\
\text { ved that white } \\
\text { in level: } 107 \mathrm{~g} \\
\mathrm{~L} \text {, and all blo } \\
\text { ellular bone } \mathrm{n} \\
\text { layed a hyper } \\
\text { blast cells, and } \\
\text { revealed a } 0.5 \\
\text { No additional } \\
\text { anel for } 43 \mathrm{~g} \\
\text { However, } \\
\text { on sequencing } \\
\text { and a FGFR } \\
\text { above } 40 \% \text {. T } \\
\text { The metaph } \\
\text { increased met } \\
\text { leukemia, and } \\
\text { ary changes ce } \\
\text { oid leukemia } \\
\text { However, the } \\
\text { diagnose acu } \\
\text { we gave hir } \\
\text { symptoms su }\end{array}$ & $\begin{array}{l}\text { Suffering fron } \\
\text { lood cell cour } \\
\text { L, blood plat } \\
\text { culture test } \\
\text { row with } 13 \text {. } \\
\text { lular bone m } \\
\text { harrow fibros } \\
\text { myeloid blas } \\
\text { normalities } \\
\text { es associated } \\
\text { parents we } \\
\text { iscovered a } \\
\text { nutation (NN } \\
\text { frequency of } \\
\text { cells were } \\
\text { olism in the } \\
\text { iffusely incre } \\
\text { sed by leuke } \\
\text { ith myelofib } \\
\text { atient's blast } \\
\text { eukemia. Bec } \\
\text { anti-infective } \\
\text { as fever and }\end{array}$ & $\begin{array}{l}\text { a recurrence of } \\
: 4.94 \times 109 / \mathrm{L} \text {, } \\
\text { et count: } 440 \times \\
\text { were negative. } \\
\% \text { myeloblasts. } \\
\text { row, increased } \\
\text { staining grade } \\
\text { cell population } \\
\text { re observed in } \\
\text { with leukemia } \\
\text { negative for } \\
\text { RAF3 mutation } \\
000142, \text { Exon5, } \\
\text { MLL was } 6.4 \% \\
\text { ot observed in } \\
\text { one marrow of } \\
\text { ed metabolism } \\
\text { ia. The patient } \\
\text { osis, TRAF3 \& } \\
\text { cell percentage } \\
\text { use his parents } \\
\text { treatment with } \\
\text { one pain were }\end{array}$ \\
\hline
\end{tabular}


On June 27, 2018, he developed fever and bone pain again. Laboratory tests displayed that white blood cell count: $6.08 \times 109 / \mathrm{L}$, neutrophil count: $2.61 \times 109 / \mathrm{L}$, hemoglobin level: 105g/L, blood platelet count: 340×109/L; LDH: 609IU/L. Bone marrow smear exhibited a hypercellular bone marrow with massive myeloblasts $(40 \%)$ and chemical staining indicating AML-M2a. Immunophenotyping analysis found bone marrow cells expressing CD33, MPO, mildly expressing CD38, CD13, CD15, CD64, CD4, consistent with AML-M2. Additionally, molecular biology tests demonstrated MLL-SEPT6 positive. The karyotype of bone marrow cells was 46, Y, -X, $\operatorname{del}(6)(q 23)$, add(11)(q23), add(22)(q13), + mar[13]/46, XY[7]. The patient was diagnosed with AML-M2a (with myelofibrosis, TRAF3 \& FGFR3 mutations, MLL-SEPT6 positive). Subsequently, he received the induction therapy with MAE regimen, his fever and bone pain alleviated after that, and then he experienced bone marrow suppression followed by hematopoietic recovery and discharge.

On August 13, 2018, and September 17, 2018, the patient was hospitalized for reassessment. The results were as followed: peripheral blood cell counts basically normal, the bone marrow smears implying complete remission, and two immunophenotyping analyses revealing $0.35 \%$ and $0.72 \%$ abnormal phenotype cells respectively. Although the MLL-SEPT6 was positive, chromosome karyotype analysis was normal during two evaluations.

Minimal residual disease and MLL-SEPT6 fusion gene tests continued to be positive after 3 cycles of standard combination chemotherapy, suggesting a poor prognosis. We recommended him to receive allogeneic hematopoietic stem cell transplantation with the aim to obtain long-term survival and improve the prognosis. In November 2018, he received a hematopoietic stem cell transplant at Peking University People's Hospital, and the donor was his father. Eight months after transplantation, the patient developed a cutaneous graft-versus-host disease manifesting as an eczematoid skin lesion. Fortunately, bone marrow examinations showed that he was in remission thereafter.

\section{Discussion}

It is a rare event that the chromosome rearrangement of $11 \mathrm{q} 23$ and Xq24s leads to the formation of the MLL-SEPT6 fusion gene. To date, only thirteen cases have been reported worldwide [8,11-17]. These leukemia patients were all in babyhood (0 29 months), including five M2 cases, four M4 cases, one M1 case, one M5 case, and two unclassified cases. Among them, one of four patients alone receiving chemotherapy survived for more than thirteen months, while two of eight patients experiencing hematopoietic stem cell transplantation prolonged their life by nine months and eleven months respectively, and the rest six of eight patients achieved long-term survival. This case is the fourteenth case worldwide. The age of onset of MLL-SEPT6 related leukemia in this case is significantly older than that in infants previously reported, suggesting that MLL-SEPT6 related leukemia can occur not only in infants but also in children. The minimal residual disease examinations and fusion gene test results failed to turn negative after three cycles of standard chemotherapy, in accord with previous reports that the prognosis of AML patients with MLL-SEPT6 was poor. Therefore, AML patients with MLL-SEPT6 may receive hematopoietic stem cell transplantation as soon as possible to obtain long-term survival.

Although the majority (65\%) of children with MLL rearrangement are diagnosed with acute lymphoblastic leukemia (ALL) [18], we speculated that the MLL-SEPT6 rearrangements are related to the development of AML rather than ALL. The formation of fusion genes between MLL and other septin family members (SEPT2, SEPT5, SEPT9, and SEPT11) is also associated with the occurrence of AML rather than ALL $[10,18,19]$. In the mouse model, MLL-SEPT6 can induce a myeloproliferative disease with long latent period, but not acute leukemia, which indicates that the occurrence of leukemia requires the mutual participation of MLL-SEPT6 and secondary genetic alterations related to DNA 
repair or cell cycle regulation [20]. Furthermore, SEPT6 deficiency did not change the phenotype of MLL-SEPT6-induced myeloproliferative disease, suggesting that SEPT6 does not act as a tumor suppressor gene [21]. Considering the lack of relevant researches, the further establishment of MLL-SEPT leukemia model in vivo and in vitro will help to clarify the mechanism of MLL-SEPT6 fusion gene in the progression of leukemia[20].

By comparing the clinical characteristics of leukemia patients with MLL-SEPT6, we found that the disease progression of this patient was slower than the others. The main clinical symptoms were bone pain and fever, no obvious signs of infection but the inflammation markers continued to rise. The symptoms could be relieved after anti-infective treatment, but they will reappear after stopping antibiotics. Although the MLL-SEPT6 fusion gene was continuously positive at the onset, the proportion of blast cells was below 20\%. The bone marrow examination results were quite different which might be a consequence due to the focal distribution of leukemia cells confirmed by PET scan. These clinical features did not appear in reported cases.

The next-generation sequencing results disclosed that the patient had TRAF3 Exon11 and FGFR3 Exon5 mutations (frequency $>40 \%$ ). TRAF3 mutation is associated with lymphoma and myeloma development [22-24] while FGFR3 mutation is associated with chondrodysplasia $[25,26]$, however neither of them is a mutation hotspot in AML. Considering that the MLL-SEPT6 fusion gene in mouse models did not directly induce AML[20], we speculated that the occurrence of MLL-SEPT6 fusion gene-associated leukemia requires the involvement of other second-hit mutational events. More case reports and laboratory data are needed to determine whether the TRAF3 and FGFR3 mutations are the second mutation events leading to leukemia. The relationship between the focal distribution of leukemia cells and the mutation of TRAF3 gene needs further exploration.

In summary, the MLL-SEPT6 associated leukemia is a rare leukemia, which can occur not only in infants but also in preschool children. Leukemia patients with MLL-SEPT6 have a poor response to chemotherapy and unfavourable clinical prognosis. Hematopoietic stem cell transplantation may be the best treatment option for these patients. In this case, although the percentage of blast cells was less than $20 \%$ due to the focal distribution of leukemia cells, bone marrow examination showed that MLL-SEPT6 fusion gene was positive, and the typical clinical manifestations of leukemia appeared. After the development of the disease, the proportion of myeloblasts eventually increased and reached the diagnostic criteria of leukemia, suggesting that clinical manifestations and fusion gene positive can be used as major criteria for the diagnosis of MLL-SEPT6 fusion gene-related leukemia.

Author Contributions: Writing-original draft preparation, Y.C. and Y.P.; review and editing, L.Z. and X.C.; data curation, W.Y. and Y.G.; critical feedback, X.Z.; supervision, L.C. All authors have read and agreed to the published version of the manuscript.

Funding: This research received no external funding.

Informed Consent Statement: Written informed consent has been obtained from the patient's mother to publish this paper.

Conflicts of Interest: The authors declare no conflict of interest.

\section{References}

1. de Boer, J.; Walf-Vorderwülbecke, V.; Williams, O. In focus: MLL-rearranged leukemia. Leukemia 2013, 27, 1224-1228, doi:10.1038/leu.2013.78.

2. Wong, N.-H.M.; So, C.W.E. Novel therapeutic strategies for MLL-rearranged leukemias. Biochim Biophys Acta Gene Regul Mech 2020, 1863, 194584, doi:10.1016/j.bbagrm.2020.194584.

3. Chen, Y.P.; Lin, H.J.; Chen, J.S.; Tsai, M.Y.; Hsieh, H.P.; Chang, J.Y.; Chen, N.F.; Chang, K.C.; Huang, W.T.; Su, W.C.; et al. CDKN1A-mediated responsiveness of MLL-AF4-positive acute lymphoblastic leukemia to Aurora kinase-A inhibitors. Int J Cancer 2014, 135, 751-762, doi:10.1002/ijc.28708.

4. Hall, P.A.; Russell, S.E. The pathobiology of the septin gene family. J Pathol 2004, 204, 489-505, doi:10.1002/path.1654. 
5. Megonigal, M.D.; Rappaport, E.F.; Jones, D.H.; Williams, T.M.; Lovett, B.D.; Kelly, K.M.; Lerou, P.H.; Moulton, T.; Budarf, M.L.; Felix, C.A. t(11;22)(q23;q11.2) In acute myeloid leukemia of infant twins fuses MLL with hCDCrel, a cell division cycle gene in the genomic region of deletion in DiGeorge and velocardiofacial syndromes. Proceedings of the National Academy of Sciences of the United States of America 1998, 95, 6413-6418.

6. Osaka, M.; Rowley, J.D.; Zeleznik-Le, N.J. MSF (MLL septin-like fusion), a fusion partner gene of MLL, in a therapy-related acute myeloid leukemia with a t(11;17)(q23;q25). Proc Natl Acad Sci U S A 1999, 96, 6428-6433, doi:10.1073/pnas.96.11.6428.

7. Taki, T.; Ohnishi, H.; Shinohara, K.; Sako, M.; Bessho, F.; Yanagisawa, M.; Hayashi, Y. AF17q25, a putative septin family gene, fuses the MLL gene in acute myeloid leukemia with $\mathrm{t}(11 ; 17)(\mathrm{q} 23 ; \mathrm{q} 25)$. Cancer Res 1999, 59, 4261-4265.

8. Ono, R.; Taki, T.; Taketani, T.; Kawaguchi, H.; Taniwaki, M.; Okamura, T.; Kawa, K.; Hanada, R.; Kobayashi, M.; Hayashi, Y. SEPTIN6, a human homologue to mouse Septin6, is fused to MLL in infant acute myeloid leukemia with complex chromosomal abnormalities involving 11q23 and Xq24. Cancer Res 2002, 62, 333-337.

9. Kojima, K.; Sakai, I.; Hasegawa, A.; Niiya, H.; Azuma, T.; Matsuo, Y.; Fujii, N.; Tanimoto, M.; Fujita, S. FLJ10849, a septin family gene, fuses MLL in a novel leukemia cell line CNLBC1 derived from chronic neutrophilic leukemia in transformation with $\mathrm{t}(4 ; 11)(\mathrm{q} 21 ; \mathrm{q} 23)$. Leukemia 2004, 18.

10. Cerveira, N.; Correia, C.; Bizarro, S.; Pinto, C.; Lisboa, S.; Mariz, J.M.; Marques, M.; Teixeira, M.R. SEPT2 is a new fusion partner of MLL in acute myeloid leukemia with $\mathrm{t}(2 ; 11)(\mathrm{q} 37 ; \mathrm{q} 23)$. Oncogene 2006, 25, 6147-6152.

11. Cerveira, N.; Micci, F.; Santos, J.; Pinheiro, M.; Correia, C.; Lisboa, S.; Bizarro, S.; Norton, L.; Glomstein, A.; Asberg, A.E.; et al. Molecular characterization of the MLL-SEPT6 fusion gene in acute myeloid leukemia: identification of novel fusion transcripts and cloning of genomic breakpoint junctions. Haematologica 2008, 93, 1076-1080, doi:10.3324/haematol.12594.

12. Borkhardt, A.; Teigler-Schlegel, A.; Fuchs, U.; Keller, C.; König, M.; Harbott, J.; Haas, O.A. An ins(X;11)(q24;q23) fuses the MLL and the Septin 6/KIAA0128 gene in an infant with AML-M2. Genes Chromosomes Cancer 2001, $32,82-88$.

13. Slater, D.J.; Hilgenfeld, E.; Rappaport, E.F.; Shah, N.; Meek, R.G.; Williams, W.R.; Lovett, B.D.; Osheroff, N.; Autar, R.S.; Ried, T.; et al. MLL-SEPTIN6 fusion recurs in novel translocation of chromosomes 3, X, and 11 in infant acute myelomonocytic leukaemia and in $\mathrm{t}(\mathrm{X} ; 11)$ in infant acute myeloid leukaemia, and MLL genomic breakpoint in complex MLL-SEPTIN6 rearrangement is a DNA topoisomerase II cleavage site. Oncogene 2002, 21, 4706-4714.

14. Fu, J.-F.; Liang, D.-C.; Yang, C.-P.; Hsu, J.-J.; Shih, L.-Y. Molecular analysis of t(X;11)(q24;q23) in an infant with AML-M4. Genes Chromosomes Cancer 2003, 38, 253-259.

15. Kim, H.-J.; Ki, C.-S.; Park, Q.; Koo, H.-H.; Yoo, K.-H.; Kim, E.-J.; Kim, S.-H. MLL/SEPTIN6 chimeric transcript from inv ins $(X ; 11)(q 24 ; q 23 q 13)$ in acute monocytic leukemia: report of a case and review of the literature. Genes Chromosomes Cancer 2003, 38.

16. Kadkol, S.S.; Bruno, A.; Oh, S.; Schmidt, M.L.; Lindgren, V. MLL-SEPT6 fusion transcript with a novel sequence in an infant with acute myeloid leukemia. Cancer Genet Cytogenet 2006, 168, 162-167.

17. Strehl, S.; König, M.; Meyer, C.; Schneider, B.; Harbott, J.; Jäger, U.; von Bergh, A.R.M.; Loncarevic, I.F.; Jarosova, M.; Schmidt, H.H.; et al. Molecular dissection of $\mathrm{t}(11 ; 17)$ in acute myeloid leukemia reveals a variety of gene fusions with heterogeneous fusion transcripts and multiple splice variants. Genes Chromosomes Cancer 2006, 45, 1041-1049.

18. Meyer, C.; Burmeister, T.; Gröger, D.; Tsaur, G.; Fechina, L.; Renneville, A.; Sutton, R.; Venn, N.C.; Emerenciano, M.; Pombo-de-Oliveira, M.S.; et al. The MLL recombinome of acute leukemias in 2017. Leukemia 2018, 32, 273-284, doi:10.1038/leu.2017.213.

19. van Binsbergen, E.; de Weerdt, O.; Buijs, A. A new subtype of MLL-SEPT2 fusion transcript in therapy-related acute myeloid leukemia with $\mathrm{t}(2 ; 11)(\mathrm{q} 37 ; \mathrm{q} 23)$ : a case report and literature review. Cancer Genet Cytogenet 2007, 176, 72-75.

20. Ono, R.; Nakajima, H.; Ozaki, K.; Kumagai, H.; Kawashima, T.; Taki, T.; Kitamura, T.; Hayashi, Y.; Nosaka, T. Dimerization of MLL fusion proteins and FLT3 activation synergize to induce multiple-lineage leukemogenesis. J Clin Invest 2005, 115, 919-929.

21. Ono, R.; Ihara, M.; Nakajima, H.; Ozaki, K.; Kataoka-Fujiwara, Y.; Taki, T.; Nagata, K.-I.; Inagaki, M.; Yoshida, N.; Kitamura, T.; et al. Disruption of Sept6, a fusion partner gene of MLL, does not affect ontogeny, leukemogenesis induced by MLL-SEPT6, or phenotype induced by the loss of Sept4. Mol Cell Biol 2005, 25, 10965-10978.

22. Edwards, S.K.E.; Baron, J.; Moore, C.R.; Liu, Y.; Perlman, D.H.; Hart, R.P.; Xie, P. Mutated in colorectal cancer (MCC) is a novel oncogene in B lymphocytes. J Hematol Oncol 2014, 7, 56, doi:10.1186/s13045-014-0056-6.

23. Mambetsariev, N.; Lin, W.W.; Stunz, L.L.; Hanson, B.M.; Hildebrand, J.M.; Bishop, G.A. Nuclear TRAF3 is a negative regulator of CREB in B cells. Proceedings of the National Academy of Sciences of the United States of America 2016, 113, 1032-1037, doi:10.1073/pnas.1514586113.

24. Mambetsariev, N.; Lin, W.W.; Wallis, A.M.; Stunz, L.L.; Bishop, G.A. TRAF3 deficiency promotes metabolic reprogramming in B cells. Sci Rep 2016, 6, 35349, doi:10.1038/srep35349.

25. Kimura, T.; Ozaki, T.; Fujita, K.; Yamashita, A.; Morioka, M.; Ozono, K.; Tsumaki, N. Proposal of patient-specific growth plate cartilage xenograft model for FGFR3 chondrodysplasia. Osteoarthritis Cartilage 2018, 26, 1551-1561, doi:10.1016/j.joca.2018.07.015.

26. Di Rocco, F.; Biosse Duplan, M.; Heuzé, Y.; Kaci, N.; Komla-Ebri, D.; Munnich, A.; Mugniery, E.; Benoist-Lasselin, C.; Legeai-Mallet, L. FGFR3 mutation causes abnormal membranous ossification in achondroplasia. Hum Mol Genet 2014, 23, 2914-2925, doi:10.1093/hmg/ddu004. 